\title{
Unemployment and Output Growth: Evidence from Upper-Middle- Income Countries in Sub-Saharan Africa
}

\author{
Ihensekhien Orobosa Abraham Ph.D \\ Department of Economics, Banking and Finance \\ Benson Idahosa University, Benin City, Edo State, Nigeria \\ Email: oihensekhien@biu.edu.ng Phone: +2348035843175 \\ Aisien Leonard Nosa Ph.D \\ Department of Economics, Banking and Finance \\ Benson Idahosa University, Benin City, Edo State, Nigeria \\ Email: lasien@biu.edu.ng
}

\begin{abstract}
Several studies have found a negative relationship between unemployment rate and output growth rate. But such has not been ascertained concerning upper middle-income countries in Sub-Saharan Africa (SSA). Hence this paper examined this relationship using Panel Least Squares and Ordinary Least Squares estimation techniques based on annual series data from 1991 to 2017. The paper observed that the average output growth rate for upper middleincome countries in SSA in the period of the study was $6.36 \%$ while that of the unemployment average rate was $15.87 \%$. The results of the panel Least Squares estimation reveals the existence of negative relationships between unemployment rate and output growth rate. In the country specific study, results from Botswana, Gabon, Mauritius and South Africa shows a positive relationship between unemployment and output growth rates revealing a case of non-inclusive growth. However, Equatorial Guinea and Namibia data on unemployment and output growth had negative relationships. The counter factual analyses conducted on the unemployment variable in term of some percentage reduction indicated that as more persons are employed there will be an increase in output growth. The findings, therefore suggests that the government should create more jobs based on labour intensive industries in upper middle-income countries in SSA, that the ratio of output growth needed to maintain stable level of unemployment rate could be sustained when there are boost in economic activities. Countries in upper middleincome in SSA that exhibited positive relationship between unemployment rate and output growth rate should concentrate more on how to increase the level of output growth rate through the boost in economic activities. Governments of these upper middle-income countries should have good policy mix focused on the reduction of unemployment at all levels.
\end{abstract}

Keywords: Upper middle-income countries, unemployment, output growth, counter factual analysis, Okun's law.

\section{Introduction}

The Sub-Saharan Africa (SSA) consists of all African states that are partially or fully located South of the Saharan Desert (United Nations, 2011). The SSA population is currently estimated at 936.1 million people and the SSA region is made up of forty eight countries (World Bank, 2018).

The International Labour Organization (ILO) report for 2017 indicated that the number of unemployed persons worldwide will hit over 201 million persons in 2017, with additional 2.7 million persons expected in 2018. The survey indicated that the third world countries, especially Africa is expected to be worst hit, where the number of the unemployed and poverty are high. The challenges of high unemployment rate and slow output growth are not only experienced by the developing countries by however, the developed countries over the years have adopted good economic and political policies to reduce the level of unemployment. In the developing countries unemployment 
challenges does not only constitute a high private cost for the individual, it is a huge cost to the government (Sachisi-Marco, 2011; Abel, Bernanke \& Croushore, 2008; Ihensekhien \& Ovenseri-Ogbomo, 2017).

Ihensekhien etal (2017) observed that the average GDP growth rate for Low income countries in SSA stood at 3.8 and the unemployment average rate was 5.9 in the time frame of 1991-2013. There empirical observation agrees with that of Okun (1962) that high rate of unemployment has been observed to affect the rate of output growth negatively. The unemployment level in a country also determines the economic well-being in the long run.

The studies of Romer and Weil (1992) revealed that unemployment can be an inhibitor to output growth in a country, in terms of deterioration of human capital resulting on a negative effect on output leading to lost of future income and saving which are harmful to output growth.

Obadan and Iyoha (1996) opined that the national economic objectives of any country is the attainment of full employment (reduction of unemployment to a minimum level) in order to have rapid output growth over time. According to Nkurunziza and Bates (2004) and Ihensekhien (2016) the SSA countries output growth rates was observed to be not high enough to make true impact in the pervasive unemployment rates that would enable the SSA countries to catch up with other developing countries of the world in the nearest future.

World Bank (2018) development indicators based on income group classification of countries revealed that the following SSA countries are upper middle income countries: Botswana, Gabon, Equatorial Guinea, Mauritius, Namibia and South Africa. Below are some basic economic facts of this upper middle in countries in SSA: Botswana is ranked as the $2^{\text {nd }}$ among forty eight of SSA with high income, it has a population of 2.2 million people with an average GDP growth rate of $4.52 \%$, average unemployment rate of $18.59 \%$, inflation rate of $2.8 \%$. Equatorial Guinea has a population of 1,324,762 million people with an average GDP growth rate of 20.19, average unemployment rate of $5.76 \%$, a median age of 22.2 years and her life expectancy at birth is 57.68 . Gabon has a population of 1.5 million, inflation rate of $-0.01 \%$, average unemployment rate of $18.46 \%$, crime index of 47.69 and safety index of 52.3 and GDP growth rate of $2.28 \%$. Mauritius is made up of a population of 1.3 million with average GDP growth rate of $5.51 \%$, average unemployment rate of $8.31 \%$ and inflation rate of $1.0 \%$. Namibia has a mean unemployment rate of $20.52 \%$, inflation rate of $6.5 \%$, a human population of 2.3 million and GDP growth of 4.18\%. South Africa is the second largest economy in SSA; it is an industrialized economy, with a population of 55.9 million, an average unemployment rate of $23.61 \%$, inflation rate of $6.3 \%$ and a mean GDP growth rate of $2.45 \%$. South Africa has a safety index of 23.37 that is considered low but with a high quality of life index of 135.57 (World Bank, 2018).

The economic conditions of the upper middle income countries in SSA are marred with high incidence of crimes, poverty, and low quality of life, severe economic and social costs of all kinds as a result of high rate of unemployment. However, the empirical study of Okun's has been verified in many countries, but this has not been verified in upper middle income countries in SSA based on the recent classification of countries into income group by the World Bank(2018). Hence, there exists a gap the literature with respect to the relationship between changes in unemployment and output growth in the upper middle income countries in SSA. The statement of the problem and the identified research gap led to raised the following objectives of this paper: to evaluate the empirical nexus between unemployment and output growth, to ascertain the rate of output growth ratio required to maintain minimum level of unemployment rate, also the counter-factual impact of unemployment rate reduction based on 5\%, $7.5 \%, 10 \%$ and so on the output growth.

The timeframe of the paper covers a period of 1991-2017. The paper is therefore divided into the following sections: section one is the introduction, literature review is in section two, section three contains the theoretical framework and methodology, section four is the presentation and the analyses of results and section five contains the summary, conclusion and recommendations.

\section{Literature Review}

2.1Conceptual Issues

The International Labour Organization (ILO, 2010) defines unemployed workers as those persons who presently do not work but who are willing to work, hence, seeking for a job. The unemployment rate in a country is the number of persons that are unemployed and is expressed as the percentage of the total labour force. The term unemployment is a stock concept considered at a point in time. Its level rises when inflow that is, the newly unemployed exceed outflows, that is people getting new jobs or quitting the labour force altogether. Unemployment is the difference between the quantity of labour employed at the going wage levels and working conditions at a given period and the quantity of labour not hired at these levels. Gbosi (1993) defined unemployment as a situation in which citizens who are willing to work at the current wage rate are unable to find jobs in a given economic environment.

Traditionally unemployment can be identified by types due to it cause. Therefore, economists often classified unemployment into frictional, structural, classical and demand-deficiency (Keynesian). Frictional unemployment occurs from the time it takes an individual to move between jobs; this also results from a normal turnover of labour. 
People who are unemployed while searching for jobs are referred to be frictionally unemployed. This situation is widespread in the Sub-Saharan Africa region due to low wage rates and the problems associated with the issues of better- working conditions.

The concept of economic growth (output growth) according to Todaro (1985) is viewed as a long -term rise in capacity to supply increasingly diverse economic goods to its population; this growing capacity is based on advancing technology and ideological adjustments that it demands. It is highly believed that economic growth leads a given population of a country to enjoy a better standard of living and improved life expectancy. Fogel (1997) opined that economic growth refers to rising per-capita income and part of this increased income is translated into the consumption of higher quantity and better quality nutrients. Through nutrition, health is measured by life expectancy responds to increases in income, reduction in unemployment level that will help reduced poverty in the long-run.

According to Dwivedi (2008) another prerequisite of economic growth is that the national output is composed of such goods and services which satisfy the maximum wants of the greatest number of people. For economic growth to be genuine, the increase in output must be sustained over a long period. The short-run increase followed by a similar decrease in output does not mean economic growth.

The discovery of a strong empirical relationship between output growth (economic growth rate) and changes in the unemployment rate as postulated by Okun's seminal paper of 1962 has become one of the most consistent relationship in macroeconomics (Adachi, 2007). Okun (1962) found that the relationship between unemployment and economic growth was both inverse and proportional. This precisely states that, a three percent increase in economic growth should result in a one percent decrease in the unemployment rate.

The subject of the negative relationship between unemployment rate and economic growth rate as postulated and empirically tested by Okun in the early 1960s has evolved from both statistical and empirical relationship that is known as empirical law called Okun's law that predicts a negative relationship between the rate of change in unemployment and the rate of change in output growth.

Okun (1962) postulated that a one percent increase in the output growth rate above the trend rate of growth (or the growth in potential output) would lead only to 3 percent in the reduction of unemployment. Reversing the causality, a one percent increase in unemployment will mean roughly more than three percent loss in output growth. This relationship indicates that the rate of output growth must be equal to its potential growth just to keep the unemployment rate constant. To reduce unemployment, therefore, the rate of output growth must be above the growth rate of potential output. (Khemraj, Madrick \& Semmler, 2006).

\subsection{Theoretical Literature}

\subsubsection{Theoretical Integration between Output Growth and Unemployment}

The debate concerning the theoretical integration between output growth and unemployment is considered as something possible and even desirable (Arico, 2001). The theoretical perspective of economic growth and unemployment began with the seminal works of Harrod (1939) and Domar (1947), followed by the works of Solow (1956) model. The issue of the long-run unemployment was totally ruled out in the neoclassical growth models which are seen as a basic tool for investigating economic expansion. In order to have extensive explanation and literature on the issues about economic growth and unemployment this could be traced to the studies of FrankelRomer on the AK approach to endogenous growth and the second model by Romer based on labour augmented where technical knowledge is found to enhance productivity. Endogenous growth and unemployment as used by Pissarides (1993) based on the benchmark of Romer (1986) and the neo-Schumpeterian approach to growth and employment by Aghion and Howitt (1994).

2.2.2 Review of Empirical and Methodological Literature

Table 1: Summary of empirical evidence on the relationship between output growth rate and unemployment rate and the methodology adopted.

\begin{tabular}{|l|l|l|l|l|l|l|l|}
\hline S/N & $\begin{array}{l}\text { Names of } \\
\text { Authors and } \\
\text { year of studies }\end{array}$ & $\begin{array}{l}\text { No. of } \\
\text { Countries }\end{array}$ & Period & $\begin{array}{l}\text { Dependent } \\
\text { variable(s) }\end{array}$ & $\begin{array}{l}\text { Independent } \\
\text { variable(s) }\end{array}$ & Methodology & $\begin{array}{l}\text { Okun's } \\
\text { Coefficient } \\
\text { Obtained }\end{array}$ \\
\hline 1 & $\begin{array}{l}\text { Prachowny } \\
(1993)\end{array}$ & $\begin{array}{l}\text { (United } \\
\text { States) }\end{array}$ & $\begin{array}{l}1975 \mathrm{Q} 1- \\
1988 \mathrm{Q} 4\end{array}$ & $\begin{array}{l}\text { Output } \\
\text { growth gap }\end{array}$ & $\begin{array}{l}\text { Capacity } \\
\text { utilization } \\
\text { gap, } \\
\text { unemployme } \\
\text { nt gap } \\
\text { Labour- } \\
\text { supply gap }\end{array}$ & $\begin{array}{l}\text { OLS(first } \\
\text { difference } \\
\text { and } \\
\text { production } \\
\text { method) }\end{array}$ & $\begin{array}{l}-0.62 \text { and - } \\
0.67\end{array}$ \\
\hline
\end{tabular}




\begin{tabular}{|c|c|c|c|c|c|c|c|}
\hline & & & & & $\begin{array}{l}\text { and hours } \\
\text { gap }\end{array}$ & & \\
\hline 2 & Weber (1995) & $\begin{array}{l}\text { 1(United } \\
\text { states) }\end{array}$ & $\begin{array}{l}\text { 1948Q1- } \\
\text { 1988Q4 }\end{array}$ & $\begin{array}{l}\text { Unemployme } \\
\text { nt gap and } \\
\text { output gap }\end{array}$ & $\begin{array}{l}\text { Output gap } \\
\text { and } \\
\text { unemployme } \\
\text { nt gap }\end{array}$ & $\begin{array}{l}\text { OLS,ARDL, } \\
\text { VAR and } \\
\text { rolling OLS }\end{array}$ & $\begin{array}{l}-0.32,-0.22 \\
\text { and }-0.26\end{array}$ \\
\hline 3 & Moosa (1997) & $\begin{array}{l}\text { 7(United } \\
\text { States, } \\
\text { France, } \\
\text { Japan, } \\
\text { United } \\
\text { Kingdom, } \\
\text { Canada, } \\
\text { Italy and } \\
\text { Germany) }\end{array}$ & $\begin{array}{l}1960- \\
1995\end{array}$ & $\begin{array}{l}\text { Unemployme } \\
\text { nt gap }\end{array}$ & $\begin{array}{l}\text { Lagged } \\
\text { unemployme } \\
\text { nt gap and } \\
\text { output gap }\end{array}$ & $\begin{array}{l}\text { OLS, rolling } \\
\text { OLS and } \\
\text { SUR }\end{array}$ & $\begin{array}{l}-0.49 \text { and }- \\
0.09\end{array}$ \\
\hline 4 & Lee(2000) & $\begin{array}{l}16 \text { OECD } \\
\text { countries } \\
\text { and } \\
\text { Germany }\end{array}$ & $\begin{array}{l}1955- \\
1999, \\
1960- \\
2006\end{array}$ & Output gap & $\begin{array}{l}\text { Unemployme } \\
\text { nt gap }\end{array}$ & $\begin{array}{l}\text { Panel least } \\
\text { squares(PLS) } \\
\text { (first } \\
\text { difference } \\
\text { and HP filter }\end{array}$ & -0.22 \\
\hline 5 & $\begin{array}{l}\text { Harris \& } \\
\text { Silverstone(2001 } \\
\text { ) }\end{array}$ & $\begin{array}{l}\text { 6( Canada, } \\
\text { Japan, US, } \\
\text {,Australia, } \\
\text { New } \\
\text { Zealand } \\
\text { and UK) }\end{array}$ & $\begin{array}{l}\text { 1978Q1- } \\
\text { 1998Q3 }\end{array}$ & $\begin{array}{l}\text { Unemployme } \\
\text { nt rate }\end{array}$ & Output rate & $\begin{array}{l}\text { ECM(first } \\
\text { difference) }\end{array}$ & $\begin{array}{l}-0.09 \text { and - } \\
0.5\end{array}$ \\
\hline 6 & $\begin{array}{l}\text { Geldenhuys \& } \\
\text { Marinkov (2007) }\end{array}$ & $\begin{array}{l}\text { 1( South } \\
\text { Africa) }\end{array}$ & $\begin{array}{l}1970- \\
2005\end{array}$ & Output gap & $\begin{array}{l}\text { Unemployme } \\
\text { nt gap }\end{array}$ & $\begin{array}{l}\mathrm{HP}, \mathrm{BN} \text { and } \\
\mathrm{BP} \text { filters }\end{array}$ & $\begin{array}{l}-0.24, \\
-1.09, \\
-0.17 \\
\text { and } \\
-0.78\end{array}$ \\
\hline 7 & $\begin{array}{l}\text { Amassoma \& } \\
\text { Nwosa (2013) }\end{array}$ & 1(Nigeria) & $\begin{array}{l}1986- \\
2010\end{array}$ & $\begin{array}{l}\text { Productivity } \\
\text { growth }\end{array}$ & $\begin{array}{l}\text { Unemployme } \\
\text { nt, labour } \\
\text { force, capital, } \\
\text { inflation and } \\
\text { government } \\
\text { expenditure }\end{array}$ & $\begin{array}{l}\text { Co } \\
\text { integration } \\
\text { and ECM }\end{array}$ & $\begin{array}{r}1.12 \\
\text { and } \\
1.35\end{array}$ \\
\hline 8 & $\begin{array}{l}\text { Akeju \& } \\
\text { Olanipekun } \\
\text { (2014) }\end{array}$ & 1(Nigeria) & $\begin{array}{l}1980- \\
2012\end{array}$ & $\begin{array}{l}\text { Unemployme } \\
\text { nt gap }\end{array}$ & Output gap & $\begin{array}{l}\text { Co } \\
\text { integration } \\
\text { and ECM }\end{array}$ & $\begin{array}{l}0.097 \\
\text { and } \\
0.069 \\
\end{array}$ \\
\hline 9 & Adachi (2007) & $\begin{array}{l}\text { 2( Japan and } \\
\text { US) }\end{array}$ & $\begin{array}{l}1969- \\
2000\end{array}$ & Output & $\begin{array}{l}\text { unemployme } \\
\text { nt }\end{array}$ & $\begin{array}{l}\text { OLS(first } \\
\text { difference) }\end{array}$ & $\begin{array}{l}-6.18 \\
\text { and } \\
-1.81 \\
\end{array}$ \\
\hline 10 & $\begin{array}{l}\text { Tombolo \& } \\
\text { Hasegawa } \\
\text { (2014) }\end{array}$ & 1(Brazil) & $\begin{array}{l}\text { 1980Q1- } \\
\text { 2013Q3 }\end{array}$ & $\begin{array}{l}\text { Unemployme } \\
\text { nt }\end{array}$ & Output & $\begin{array}{l}\text { OLS (first } \\
\text { difference ) }\end{array}$ & $\begin{array}{l}-0.1878 \\
-0.2055\end{array}$ \\
\hline 11 & Kargi (2013) & $\begin{array}{l}34 \text { OECD } \\
\text { countries }\end{array}$ & $\begin{array}{l}1987- \\
2012\end{array}$ & $\begin{array}{l}\text { Unemployme } \\
\text { nt }\end{array}$ & Output & $\begin{array}{l}\text { OLS(first } \\
\text { difference) }\end{array}$ & -0.27 \\
\hline 12 & Boulton (2010) & $\begin{array}{l}10 \text { (eastern } \\
\text { European } \\
\text { countries) }\end{array}$ & $\begin{array}{l}1991- \\
2008\end{array}$ & Real GDP & $\begin{array}{l}\text { Unemployme } \\
\text { nt }\end{array}$ & $\begin{array}{l}\text { OLS (first } \\
\text { difference) }\end{array}$ & $\begin{array}{l}0.83 \\
-4.2 \\
-3.44\end{array}$ \\
\hline
\end{tabular}




\begin{tabular}{|c|c|c|c|c|c|c|c|}
\hline & & $\begin{array}{l}\text { Poland, } \\
\text { Romania, } \\
\text { Slovakia, } \\
\text { Slovenia, } \\
\text { Bulgaria, } \\
\text { Czech } \\
\text { Republic, } \\
\text { Hungary, } \\
\text { Latvia and } \\
\text { Lithuania }\end{array}$ & & & & & $\begin{array}{l}-4.54, \\
2.71, \\
0.26, \\
-5.44, \\
1.87 \\
\text { and } \\
-2.74\end{array}$ \\
\hline 13 & $\begin{array}{l}\text { Madito \& } \\
\text { Khumalo (2014) }\end{array}$ & $\begin{array}{l}\text { 1(South } \\
\text { Africa) }\end{array}$ & $\begin{array}{l}\text { 1967Q1- } \\
\text { 2013Q4 }\end{array}$ & $\begin{array}{l}\text { Economic } \\
\text { growth rate }\end{array}$ & $\begin{array}{l}\text { Unemployme } \\
\text { nt rate }\end{array}$ & $\begin{array}{l}\text { VECM(first } \\
\text { difference) }\end{array}$ & -0.618 \\
\hline 14 & $\operatorname{Ho}(2002)$ & 1(Macau) & $\begin{array}{l}1993- \\
2001\end{array}$ & Output & $\begin{array}{l}\text { Unemployme } \\
\text { nt }\end{array}$ & $\begin{array}{l}\text { OLS(first } \\
\text { difference) }\end{array}$ & -1.6951 \\
\hline 15 & Andrei (2009) & 1(Romania) & $\begin{array}{l}24 Q 000 \\
\text { Q1-2008 }\end{array}$ & Output gap & $\begin{array}{l}\text { Unemployme } \\
\text { nt gap }\end{array}$ & OLS & -0.493 \\
\hline 16 & $\begin{array}{l}\text { Hutengs \& } \\
\text { Stadtmann } \\
(2012)\end{array}$ & Euro zone & & $\begin{array}{l}\text { Unemployme } \\
\text { nt }\end{array}$ & GDP & $\begin{array}{l}\text { OLS(first } \\
\text { difference }\end{array}$ & $\begin{array}{l}-0.034,- \\
0.91,-0.75 \\
\text { and }-0.234\end{array}$ \\
\hline 18 & $\begin{array}{l}\text { Zanin \& Marra } \\
\text { (2012) }\end{array}$ & $\begin{array}{l}\text { 9(Spain, } \\
\text { Portugal, } \\
\text { The } \\
\text { Netherlands, } \\
\text { Italy, } \\
\text { Ireland, } \\
\text { Greece, } \\
\text { Finland, } \\
\text { Austria and } \\
\text { France }\end{array}$ & $\begin{array}{l}1996- \\
2009\end{array}$ & $\begin{array}{l}\text { Unemployme } \\
\mathrm{nt}\end{array}$ & $\begin{array}{l}\text { Real GDP } \\
\text { growth }\end{array}$ & $\begin{array}{l}\text { OLS and } \\
\text { rolling } \\
\text { OLS(first } \\
\text { difference) }\end{array}$ & $\begin{array}{l}-0.34,-0.14, \\
-0.19,-0.05,- \\
0.31,-0.07,- \\
0.12,-0.32 \\
\text { and- } 0.10\end{array}$ \\
\hline 19 & $\begin{array}{l}\text { Barreto \& } \\
\text { Howland (1993) }\end{array}$ & 1(Japan) & $\begin{array}{l}1953- \\
1982\end{array}$ & $\begin{array}{l}\text { Unemployme } \\
\text { nt } \\
\text { Output }\end{array}$ & $\begin{array}{l}\text { Output } \\
\text { Unemployme } \\
\text { nt }\end{array}$ & $\begin{array}{l}\text { OLS(first } \\
\text { difference) }\end{array}$ & $\begin{array}{l}-0.032 \\
-9.46\end{array}$ \\
\hline 20 & Tatoglu (2011) & $\begin{array}{l}19 \text { European } \\
\text { countries }\end{array}$ & $\begin{array}{l}1977- \\
2008\end{array}$ & $\begin{array}{l}\text { Unemployme } \\
\text { nt } \\
\text { Output }\end{array}$ & $\begin{array}{l}\text { Output } \\
\text { Unemployme } \\
\text { nt }\end{array}$ & $\begin{array}{l}\text { Panel co } \\
\text { integration } \\
\text { and Panel } \\
\text { ECM }\end{array}$ & $\begin{array}{l}0.003, \\
0.007 \\
-0.087 \\
-0.075\end{array}$ \\
\hline 21 & $\begin{array}{l}\text { Ozel \& Sezgin } \\
(2013)\end{array}$ & $\begin{array}{l}7\{\text { Industrial } \\
\text { countries }(\mathrm{G} \\
7)\}\end{array}$ & $\begin{array}{l}2000- \\
2011\end{array}$ & $\begin{array}{l}\text { Unemployme } \\
\text { nt rate }\end{array}$ & $\begin{array}{l}\text { Growth rate } \\
\text { and } \\
\text { Productivity }\end{array}$ & $\begin{array}{l}\text { Panel least } \\
\text { squares, } \\
\text { Fixed and } \\
\text { Random } \\
\text { effects }\end{array}$ & $\begin{array}{l}-0.351 \\
-0.250\end{array}$ \\
\hline 22 & $\begin{array}{l}\text { Khemraji ; } \\
\text { Madrick \& } \\
\text { Semmler (2006) }\end{array}$ & $\begin{array}{l}\text { 4(US, } \\
\text { France, UK } \\
\text { and } \\
\text { Germany }\end{array}$ & $\begin{array}{l}1961- \\
2000\end{array}$ & Output & $\begin{array}{l}\text { Unemployme } \\
\mathrm{nt}\end{array}$ & $\begin{array}{l}\text { OLS(first } \\
\text { difference) }\end{array}$ & $\begin{array}{l}-9.83 \\
-3.12 \\
-4.36 \\
-5.67 \\
\end{array}$ \\
\hline 23 & Elshamy (2013) & 1(Egypt) & $\begin{array}{l}1970- \\
2010\end{array}$ & Output & $\begin{array}{l}\text { Unemployme } \\
\text { nt }\end{array}$ & $\begin{array}{l}\text { OLS,ECM(G } \\
\text { ap model) }\end{array}$ & -0.021 \\
\hline 24 & Salman (2012) & 1(Sweden) & $\begin{array}{l}\text { 1993Q1- } \\
\text { 2011Q2 }\end{array}$ & $\begin{array}{l}\text { GDP growth } \\
\text { rate }\end{array}$ & $\begin{array}{l}\text { Total } \\
\text { unemployme } \\
\text { nt, Female } \\
\text { and male } \\
\text { unemployme } \\
\text { nt }\end{array}$ & $\begin{array}{l}\text { OLS(first } \\
\text { difference) }\end{array}$ & $\begin{array}{l}-0.076 \\
-0.084 \\
-0.079\end{array}$ \\
\hline
\end{tabular}




\begin{tabular}{|c|c|c|c|c|c|c|c|}
\hline 25 & $\begin{array}{l}\text { Ihensekhien } \\
\text { (2016) }\end{array}$ & $\begin{array}{l}42 \text { (SSA } \\
\text { countries) }\end{array}$ & $\begin{array}{l}1991- \\
2013\end{array}$ & $\begin{array}{l}\text { Unemployme } \\
\text { nt }\end{array}$ & $\begin{array}{l}\text { GDP growth } \\
\text { rate }\end{array}$ & $\begin{array}{l}\text { Panel Least } \\
\text { Squares and } \\
\text { OLS }\end{array}$ & -0.049 \\
\hline 26 & $\begin{array}{l}\text { Ihensekhien \& } \\
\text { Erhi (2016) }\end{array}$ & Nigeria & $\begin{array}{l}1991- \\
2015\end{array}$ & $\begin{array}{l}\text { GDP growth } \\
\text { rate }\end{array}$ & $\begin{array}{l}\text { Total } \\
\text { unemployme } \\
\text { nt rate, Youth } \\
\text { unemployme } \\
\text { nt rate, Male } \\
\text { unemployme } \\
\text { nt rate and } \\
\text { Female } \\
\text { unemployme } \\
\text { nt rate }\end{array}$ & OLS & $\begin{array}{l}53.45 \\
1041 \\
26.23 \\
14.03\end{array}$ \\
\hline 27 & $\begin{array}{l}\text { Ihensekhien \& } \\
\text { Asekome (2017) }\end{array}$ & $\begin{array}{l}23 \text { (Low } \\
\text { income } \\
\text { countries in } \\
\text { SSA) }\end{array}$ & $\begin{array}{l}1991- \\
2013\end{array}$ & $\begin{array}{l}\text { Youth } \\
\text { unemployme } \\
\text { nt rate }\end{array}$ & $\begin{array}{l}\text { GDP growth } \\
\text { rate }\end{array}$ & $\begin{array}{l}\text { Panel Least } \\
\text { Squares and } \\
\text { OLS }\end{array}$ & -0.171 \\
\hline 28 & $\begin{array}{l}\text { Ihensekhien\& } \\
\text { Ovenseri- } \\
\text { Ogbomo (2017) }\end{array}$ & $\begin{array}{l}23 \text { (Low } \\
\text { income } \\
\text { countries in } \\
\text { SSA) }\end{array}$ & $\begin{array}{l}1991- \\
2013\end{array}$ & $\begin{array}{l}\text { Total } \\
\text { unemployme } \\
\text { nt rate }\end{array}$ & $\begin{array}{l}\text { GDP growth } \\
\text { rate }\end{array}$ & $\begin{array}{l}\text { Panel Least } \\
\text { squares and } \\
\text { OLS }\end{array}$ & -0.075 \\
\hline 29 & $\begin{array}{l}\text { Mojica, \& } \\
\text { Tatlonghari, } \\
\text { (2017) }\end{array}$ & $\begin{array}{l}\text { Philippines } \\
\text { economy }\end{array}$ & $\begin{array}{l}\text { 1990Q3- } \\
\text { 2014Q3, } \\
\text { 1990Q3- } \\
\text { 2005Q3, } \\
\text { 2005Q3- } \\
\text { 2014Q\# }\end{array}$ & $\begin{array}{l}\text { Unemployme } \\
\text { nt rate }\end{array}$ & $\begin{array}{l}\text { GDP growth } \\
\text { rate }\end{array}$ & OLS & $\begin{array}{l}-0.85 \\
-0.92 \\
-0.70\end{array}$ \\
\hline
\end{tabular}

\section{Theoretical Framework and Methodology}

\subsection{Theoretical Framework}

The relationship between economic growth and the unemployment rate based on theoretical linkage could be traced to one school of economic thought or the other. The classical economist's school of thought believed that the connection between economic growth and unemployment is a one-way linkage that exists between the inputs of labour to economic growth.

Kaldor (1967) as cited in Obadan and Odusola (2000) in invoking the Verdoorn's law states that faster growth of output is responsible for a faster growth of productivity.

The positive relationship that exists between employment and economic growth was also confirmed by Dernburg and McDougall (1985). Also from the view of the classical economists referring to Cobb-Douglas production function based on the technical links between output and the inputs such as labour and capital. The model indicated that the level of labour force assuming other variable is assumed to be constant help to determine the growth rate of output.

From the Keynesian economists' angle, the issue of output and unemployment is explained in terms of aggregate demand. The Keynesians believed that the demand for labour as a case of derived demand. The Keynesian theoretical linkages for economic growth and unemployment as analyzed by Hussain and Nadol (1997), Thirlwal (1997) and Grill and Zanalda (1995) implies that increase in employment, technological change and investment are largely endogenous.

In a nut-shell, the growth of employment/unemployment is the determinants of long term increase in economic growth influenced by the level of unemployment/employment rate of a country.

The theoretical connection of economic growth and unemployment began with the works of Harrod (1936), Domar (1947) and Solow (1956) in their investigation of the issue of the long-run unemployment in influencing the level of economic growth. The extention of the Keynesian model could be found in the studies of Okun (19962). Theoretically Okun's law establishes the linkages between economic growth rate and unemployment rate, which he ascertained empirically to be negative. Okun's law is seen as a benchmark for determining the economic well-being of a country.

The economic implication of the Okun's coefficient is that a $1 \%$ reduction in the unemployment rate would result in $3 \%$ or more increase in the level of economic growth rate of a country. However, Okun's law shows clearly a direct 
link between economic growth rate and the unemployment rate. Hence, to determine a given level of the unemployment, what level of economic growth should the policymakers/government expect based on the sample periods for a given study.

3.2 Methodology

This paper adopted the use of annual data covering a cross-section of six upper middle income countries in SSA as classified by the recent development indicators of the World Bank (2018). The timeframe of this study covers a period of 1991-2017. The paper applied the use of annual time series to determine the relationship between changes in unemployment rate and output growth rate among the upper middle income countries in SSA inorder to ascertain whether Okun's law is applicable in these countries. Panel Least Squares and the Ordinary Least Squaers estimation methods was applied in this paper. The use application of annual data were observed in the studies of Moosa (1997), Viren (2001) and Ihensekhien etal (2016 and 2017)

3.2.1 Model Specification

Adopted the use of the first difference version of Okun's, the difference version has been applied in many empirical studies due to its purely statistical and simple calculations which can be directly evaluated from the available empirical data. (Hilmer \& Hilmer, 2014). The studies of Barreto and Howland (1993) revealed that the direction of the regression equation, that is the output growth regressed on unemployment or unemployment regressed on output growth is ascertained by the researcher's research question. Hence, this study Okun's equation in terms of the first difference is stated as: $U N E_{t}-U N E_{t-1}=\alpha+\beta\left(O G R_{t}-O G R_{t-1}\right)+e_{t}$

Inorder to express the cross- sectional nature of the equation (1) above, this equation is respecified as: $U N E_{i, t}-U N E_{i, t-1}=\alpha+\beta\left(O G R_{i, t}-O G R_{i, t-1}\right)+e_{i, t}$

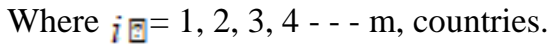

$\mathrm{t}=1,2,3,--\mathrm{n}$, years.

Where: $\mathrm{UNE}_{\mathrm{i}, \mathrm{t}}=$ the observed unemployment rate of countries $\mathrm{i}$.

$O G R_{i, t}=$ the GDP growth rate (Output growth rate) of Upper middle-income countries in SSA.

$\alpha=$ the intercept, which indicates the average output growth of full-employment output (potential output). $\beta$ = the Okun's coefficient, which was estimated by Okun to be negative $(\beta<0)$.

The term $\beta$ shows the variation in changes in output growth rate as a result of a unit change in unemployment rate.

$e_{i, t}=$ error term. The error term is assumed to contain some different information such as factors affecting the dependent variable that are not used as the independent variables, specification errors, and the issues concerning the inherent randomness in human character (Hilmer etal, 2014).

The equation (2) is re-specified to include logarithms since the study is interested in the percentage change in terms of output growth rate and rate: $\log U N E_{i, t}-\log U N E_{i, t-1}=\alpha+\beta\left(\log O G R_{i, t}-\log O G R_{i, t-1}\right)+e_{i, t}$

The rate of output growth needed for a stable unemployment rate will be determined based on the formula: Rate of output ratio $=-\left(\frac{\alpha}{-\beta}\right)$

Equation (4) indicates the ratio of how much the economy of a country must grow to sustain a stable level of unemployment rate.

The value $\frac{\alpha}{\beta}$ is the minimum level of output growth needed to reduce the unemployment rate (Knotek, 2007).

4. Presentation and Analyses of Results

4.1 Presentation of Empirical Results.

Table 2: Results of Panel Unit Root Tests

\begin{tabular}{lll}
\hline Method (At levels) & OGR & UNE \\
\hline Levin,Lin \& Chut** & $-5.33(0.000)^{*}$ & $-0.069(0.472)$ \\
\hline Im,Pesaran and Shin W-Star & $-5.38(0.000)^{*}$ & $-1.707(0.044)$ \\
\hline
\end{tabular}




\begin{tabular}{lll}
\hline ADF-Fisher Chi-Square & $51.39(0.000)^{*}$ & $20.419(0.059)$ \\
\hline PP-Fisher Chi-Square & $89.70(0.000)^{*}$ & $11.46(0.490)$ \\
\hline Method (At first difference) & OGR & UNE \\
\hline Levin,Lin \& Chut** & & $-1.050(0.147)$ \\
\hline Im,Pesaran and Shin W-Star & & $-2.724(0.003)^{* *}$ \\
\hline ADF-Fisher Chi-Square & & $29.787(0.003)^{* *}$ \\
\hline PP-Fisher Chi-Square & $51.44(0.000)^{*}$ \\
\hline
\end{tabular}

Author's Estimation Results (2018)

$* / * *$ represents significance at $1 \% \& 5 \%$ level.

The results indicated that the t-statistic values obtained were found to be statistically significant when compared with the critical values for decision making on the the hypotheses which was also confirmed by the probability values represented in parentheses. Table 2 showed that the unemployment variable was observed not to be stationary at levels but was stationary at the first difference hence the variables of output growth and unemployment were found to be statistically suitable for further statistical analyses and forecasting purpose. It means that the null hypothesis of the presence of non-Ststionarity in the panel data series is rejected.

Table 3: Panel Least Squares Estimation Results for the overall sample of upper middle-income countries in SSA. Unemployment rate (UNE) as the dependent variable and Output growth rate (OGR) as the independent variable.

\begin{tabular}{|c|c|c|c|c|c|c|c|c|}
\hline Category of Countries & $\begin{array}{l}\text { AOG } \\
\text { R }\end{array}$ & $\begin{array}{l}\text { AUN } \\
\mathbf{E}\end{array}$ & $\alpha$ & $\beta$ & $\begin{array}{l}\text { t- } \\
\text { stat }\end{array}$ & $\begin{array}{l}\text { Prob.Val } \\
\text { ue }\end{array}$ & $\mathbf{R}$ & $\frac{1}{\beta}$ \\
\hline $\begin{array}{l}6 \\
\text { countries }\end{array}$ & 6.36 & 15.87 & $\begin{array}{l}16.77 \\
3\end{array}$ & $\overline{-}-142$ & $\begin{array}{l}- \\
4.05 \\
*\end{array}$ & 0.000 & 118.1 & 7.04 \\
\hline $5 \%$ reduction in UNE & & 15.08 & $\begin{array}{l}15.95 \\
4\end{array}$ & $-\overline{0}$ & $\begin{array}{l} \\
4.05 \\
*\end{array}$ & 0.000 & 118.2 & 7.41 \\
\hline $7.5 \%$ reduction in UNE & & 14.68 & $\begin{array}{l}15.51 \\
5\end{array}$ & $\overline{0}-131$ & $\begin{array}{l} \\
4.05 \\
* \\
\end{array}$ & 0.000 & 118.4 & 7.63 \\
\hline $10 \%$ reduction in UNE & & 14.29 & $\begin{array}{l}15.09 \\
6\end{array}$ & $\begin{array}{l}- \\
0.127\end{array}$ & $\begin{array}{l}- \\
4.05 \\
*\end{array}$ & 0.000 & 118.9 & 7.87 \\
\hline $15 \%$ reduction in UNE & & 13.49 & $\begin{array}{l}14.25 \\
7\end{array}$ & $\begin{array}{l}- \\
0.120\end{array}$ & $\begin{array}{l} \\
4.05 \\
*\end{array}$ & 0.000 & 118.8 & 8.33 \\
\hline $20 \%$ reduction in UNE & & 12.70 & $\begin{array}{l}13.41 \\
8\end{array}$ & $\begin{array}{l}- \\
0.113\end{array}$ & $\begin{array}{l}- \\
4.05 \\
*\end{array}$ & 0.000 & 118.7 & 8.85 \\
\hline $50 \%$ reduction in UNE & & 7.94 & 8.387 & 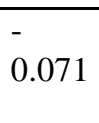 & $\begin{array}{l}- \\
4.05 \\
*\end{array}$ & 0.000 & 118.1 & $\begin{array}{l}14.0 \\
9\end{array}$ \\
\hline
\end{tabular}

Source: Author's Estimation Results (2018)

* represents significance at $1 \%$ level.

Note: $\alpha=$ intercept, $\beta=$ Okun's coefficient, $\mathrm{R}=$ rate of output ratio $=-\left(\frac{\alpha}{-\beta}\right)$

The estimation results for the upper middle-income countries in SSA based on the first differenced equation using panel data method of panel least Squares was used to determine the relationship between output growth rate (OGR) and unemployment rate (UNE). Table 3 indicated that unemployment rate is negatively related to output growth rate and the t-statistic value was found to be statistically significant. The Okun's coefficient for upper middle-income countries in SSA indicated the negative relationship of the variables used as shown in table 4.1.2 with Okun's coefficient of -0.142 indicates that a one percent decrease in unemployment led to 0.142 percent increase in output 
growth rate and the needed rate of output growth for stable unemployment for the upper middle-income countries is 118.1 and the Okun's inverse $\left(\frac{1}{\beta}\right)$ of 7.04 indicated that as unemployment rate falls by one percent output growth would increased by 7.04 percent within the period. However, counter factual analyses were conducted based on some percentage reduction in the unemployment rate the result obtained indicated that as more persons are employed the level of output would increase. Based on the empirical results obtained as shown in table 4.1.2 using the t-statistic and the probability values indicated that Okun's law is applicable in the upper middle- income countries of SSA since it is statistically significant.

Hence, this led to the empirical investigation of individual countries that made up the upper middle-income countries in SSA to ascertain whether Okun's law is applicable in these countries; the results are shown in table 4.

Table 4: OLS Estimation Results for Upper Middle - Income Countries in SSA. Unemployment rate (UNE) as the dependent variable and Output growth rate (OGR) as the independent variable.

\begin{tabular}{lccccccccc}
\hline Countries & AOGR & AUNE & $\alpha$ & $\beta$ & t-stat & $\begin{array}{l}\text { Prob. } \\
\text { Value }\end{array}$ & $\boldsymbol{R}$ & $\boldsymbol{A R}$ & $\frac{1}{\beta}$ \\
\hline Botswana & 4.52 & 18.59 & 18.27 & 0.072 & 0.594 & 0.558 & - & -9.4 & 13.88 \\
\hline $\begin{array}{l}\text { Equatorial } \\
\text { Guinea }\end{array}$ & 20.19 & 5.76 & 5.76 & - & -0.009 & 0.992 & 360 & 13.3 & 62.5 \\
\hline Gabon & 2.28 & 18.46 & 18.17 & 0.129 & $2.201^{* *}$ & 0.037 & - & -5.22 & 7.75 \\
\hline Mauritius & 5.51 & 8.31 & 7.74 & 0.125 & 1.113 & 0.276 & - & -2.29 & 8.00 \\
\hline Namibia & 4.18 & 20.52 & 20.86 & - & -0.714 & 0.482 & 251.3 & 9.31 & 12.05 \\
\hline $\begin{array}{l}\text { South } \\
\text { Africa }\end{array}$ & 2.45 & 23.61 & 23.43 & 0.069 & 0.265 & 0.793 & - & - & 14.49 \\
\hline
\end{tabular}

Source: Author's Estimation Results (2018)

Where: ** represents significance at 5\% level.

AUNE $=$ average unemployment rate

AOGR $=$ average output growth rate

$\alpha=$ Intercept term

$\beta=$ Okun's coefficient

Rate of output ratio $(R)=-\left(\frac{\alpha}{-\beta}\right)$

$\mathrm{AR}=$ average rate of output ratio for the period of study

Table 4 contains six upper middle-income countries out of which two of the countries OLS results revealed the expected negative relationship between output growth rate and unemployment rate. However, only one country out of the six upper middle income countries had her individual t-statistic value to be statistically significant at $5 \%$ as reflected in table 4. However, the empirical results in table 4 indicated the non existence of Okun's law in these countries contrary to the panel least squares result. It was observed that the Okun's coefficients for some of these countries had very low magnitude and the results further indicated that Okun's coefficient varies among countries as a result of the level of the influence of the unemployment rate on output growth rate.

A comparison of the average output growth rate (AOGR) variable for upper middle income countries of 6.36 revealed that some countries within the upper middle income group falls below the calculated average in countries such as Botswana had 4.52, Gabon 2.28, Mauritius 5.51, Namibia 4.18 and South Africa 2.45 except Equatorial Guinea that had a high average output growth rate of 20.19. The calculation of the rate of output growth rate needed for stable unemployment rate shows that some countries in the upper middle income group in SSA has to grow at a very higher rate as observed in Equatorial Guinea and Namibia this was also revealed in the average ratio of the output growth needed to sustain a minimum level of unemployment rate in these countries, which implies a serious threat to economic, political as well as social interests of these countries due to increasing unemployment situations. 
The issue of the positive relationship regarding empirical signs observed in South Africa, Equatorial Guinea, Gabon and Mauritius between output growth rate and unemployment rate follows the argument of saint-Paul (1993), Davis and Haltiwanger (1992) while Bean and Pissarides (1993) indicated that the bivariate correlation between output growth rate and unemployment rate can be either positive or negative depending on the economic structure and the magnitude of growth. The work of Aghion and Howitt (1994) agreed that high rates of economic growth are negatively correlated with unemployment and low rates of economic growth are positively correlated with unemployment. The issues of the positive empirical sign were also observed in some of the low income countries category such as Guinea-Bissau, Guinea, Niger and Zimbabwe these countries were observed to have low economic growth rate that could be responsible for such factors as poverty, underutilization of natural and mineral as well low human resources development (Ihensekhien \&Asekome, 2017).

5. Summary, Conclusions and Recommendations

The paper reflects the empirical relationship between unemployment rate and output growth rate in upper middleincome countries in SSA. Annual data series covering a time frame of 1991 to 2017 period based on six upper middle-income countries in SSA region were evaluated based on a balanced panel data series where panel least squares was employed and that of the individual countries were the ordinary least squares techniques were employed to test the empirical estimation. The various statistical as well as empirical results were quite revealing indicating the inverse relationship between output growth rate and unemployment rate variables in the Panel Least Squares result, however, some countries had positive relationships instead of the negative relationships, which further indicated the non existence of Okun's relationship and applicability within some upper middle -income countries in SSA. The paper study also shows that the Okun's coefficients vary across countries in terms of its coefficient magnitude. Also a counter factual analyses were conducted based on some percentage reduction in the unemployment rate, the empirical evidence indicated the needed to reduced unemployment level in order to boost output growth in these upper middle-income countries in SSA.

From the various findings of the paper, the following are therefore recommend: that the governments of these upper middle-income countries should promote more jobs creation in order to boost the level of economic activities in these countries that the government should encouraged investment that are based on labour intensive employment opportunities. Governments of these upper middle-income countries should have good policy mix focused on the reduction of unemployment at all levels.

References

Abel, A.B., Bernanke, B.S., \& Croushore, D., (2008). Macroeconomics. Boston: Pearson Education Inc.

Adachi, H., (2007). Economic Growth and Unemployment: Theoretical Foundations of Okun's Law. Review of Economics and Statistics.

Aghion P., \& Howitt, P., (1994). "Growth and Unemployment”, Review of Economic Studies 61, 477-94.

Akeju, K.F., \& Olanipekun, D.B., (2014). Unemployment and Economic Growth in Nigeria. Journal of Economic and Sustainable Development, 5(4), 138-144.

Amossoma, D., \& Nwosa, P.I., (2013). The impact of unemployment rate in productivity growth in Nigeria: An error correction modeling approach. International Journal of Economics and Management Sciences. 2(28), $1-13$

Arico, F.R., (2001). Growth and Unemployment towards a Theoretical Integration. Review of Economic Studies 96, $1-41$

Barreto, H., \& Howland, F. (1993), “there are two Okun's law relationships between output and unemployment”. Working paper, Wabash College

Bean, C., \& Pissarides, C., (1993). Unemployment, Consumption and Growth, European Economic Review, 37, $837-854$.

Boultom, T., (2010). Test of Okun's Law for the 10 Eastern European Countries, London Metropolitan Business School, and Economics Subject Group.

Davis, S.J., \& Haltiwangerk, J., (1993). “Gross Job Creation, Distribution and Employment Reallocatio, “Quarterly Journal of Economics, 107, 819-864.

Derngurg, T.F., \& McDougall, D.M. (1985). Macroeconomics, 7 Ed. New York: McGrew Hill.

Domar, E.D., (1947). "Expansion and Employment", American Economic Review, 37, 1, 345-55 in. Domer E.D. (1957) "Essays in the Theory of Economic Growth" Oxford University Press Oxford.

Dwivedi, D.N., (2008). Managerial Economics, Seventh Edition, Vikas Publishing House, New Delhi.

Elshamy, H. (2013). Okun's law and its validity in Egypt. Journal of Emerging Issues in Economics, Finance and Banking, Vol.1 No.2 
Fogel, R.W., (1997). New Findings on Secular Trends in Nutrition and Mortality: Some Implications for Population Theory, M. Rossenzweing and O. Stark (Eds.) The Hand Book of Population and Family Economics. W.I.A, Amsterdam.

Gbosi, A.N., (1993). Unemployment and Economic Growth in Nigeria, Ikot Abasi: Gabby Associates.

Geidenhuys, J., \& Marinkov, M., (2007). Robust Estimates of Okun's Coefficient for South Africa. Working Paper Number 55. Department of Economics, University of the Frees State 1-18.

Harrod, R.E., (1939). “An Essay in Dynamic Theory”, Economic Journal, in Harrod R.F., (1972), "Economic Essays", London, Macmillan Economic Press 256.

Hilmer, C.E. \& Hilmer, M.J. (2014). Practical Econometrics (Data Collection, Analysis and Application). McGrawHill International Edition, New York.

Ho, W.S. (2002). Okun coefficient at Macao: Estimations and applications. 2002 Monetary Authority of Macao, 7591.

Ihensekhien, O.A (2016). A cross country empirical analysis of the relationship between Economic growth and Unemployment in Sub-Saharan Africa, An unpublished Ph.D (Economic) Thesis of Benson Idahosa University.

Ihensekhien O.A \& Erhi M.A (2016). Economic growth and unemployment categories: Evidence from Nigeria. West African Social and Management Sciences Review (WASMSR) Vol. 7

Ihensekhien, O.A \& Asekome, M.O (2017) Youth unemployment and economic growth: Lesson from Low-income countries in Sub-Saharan Africa. European Journal of Economics, Law and Politics (ELP), Vol. 4, No.2.

Ihensekhien, O.A. \& Ovenseri-Ogbomo, F.O. (2016). Unemployment and economic growth: Evidence from Low income countries in Sub-Saharan Africa. Journal of Finance, Banking and Investment, Vol.4. No.2.

International Labour Organization (ILO, 2010). ILO Statistics of 2010.

International Labour Organization (ILO, 2017). Global Employment Trends for Youth.

Kargi, B., (2014). Okun's Law and Long Term Co-integration Analysis for OECD countries (1987-2012) international Research Journal of Finance.

Khemraj, T., Madrick, J., \& Semmler, W., (2006). Okun's Law and Jobless Growth. New School for Social Research, Online at http://mpora.ub.uni-muenchen.de/5488//

Knotek, E.S., (2007). “How useful is Okun's Law? Federal Reserve Bank of Kensas, Journal of Economic Review, 4, 73-103.

Lee, J., (2000). The Robustness of Okun's Law: Evidence from OECD Countries, Journal from Macroeconomics, 22, 331-356.

Madito, O., \& Khumato, J., (2014). Economic Growth-Unemployment Nexus in South Africa: VECM Approach. Mediterranean Journal of Social Sciences, 5(20), 79-84.

Moosa, I.A., (1997). A Cross - Country Comparison of Okun's Coefficient, Journal of Comparative Economics 24(3), 335-356

Moosa, I.A., (1999). Cyclical Output, Cyclical Unemployment and Okun's Coefficient, Structural Time Series Approach, International Review of Economics and Finance, 8, 293-304.

Mojica, M.A \& Tatlonghari, V.M (2017). The relationship between output growth and unemployment in the Philippines economy (1990-2014): An empirical analysis of variants of Okun's Law, Journal of Emerging Economies and Islamic Research.5 (1) www.jeeir.com

Nadol, C., \& Hussain, M. N. (1997). Employment and growth: Some empirical evidence from structural time series model. Applied Economics, 33(8), 1083-1088.

Nkurunziza, J.P., \& Bates R.H., (2004). Political Institutions and Economic Growth in Africa (Centre for International Development Working Paper, No.98), Harvard University.

Obadan, M.I., \& Odusola, F.A. (2000) Productivity and unemployment in Nigeria. Ibadan: National Centre for Economic Management and Administration (NCEMA)

Okun, A. (1962), "Potential GNP: its measurement and significance" Proceedings of the Business and Economic Statistics section of the American Statistical Association, pp 98-104.

Ozel, H.A, Sezgin,F.H \& Topkaya,O.(2013) Investigation of Economic growth and unemployment relationship for G7 countries using regression analysis. International journal of Business and Social Sciences. Vol.4 (6)

Pissarides, C., (1990). Equilibrium Unemployment Theory, Oxford, Blackwell.

Pissarides, C., (1992). "Loss of skills during unemployment and persistence of employment shocks" Quarterly Journal of Economics, 107 (4), 1371-1391.

Prachowny, M.F.J., (1993). Okun's Law: Theoretical Foundation, and Revised Estimates, Review of Economics and Statistics, 75, 331-336.

Romer, P., (1986). "Increasing Returns and Long-run Growth”, Journal of Political Economy, 94, $1002-1036$. 
Mankiw, N.G., Romer, D. \& Weil, D.N. (1992) A Contribution to the empirics of economic growth. Quarterly Journal of Economics, 107, 407-437.

Saint - Paul, G.J., (1992). Productivity growth and the structure of the business cycle, European Economic Review.

Salman, A.K., (2012). Testing the Causal Nexus between Output and Unemployment: Swedish Data. International Business Research. 5(10), 29-45.

Sanchis-i-Marco, M., (2011). Falacias, dilamas y Paradojas, La Economia Espanola: 1980-2010, publicaciones de la Universidad de Valencia.

Semmler, W., \& Zhang, W., (2005). "The Impact of Output Growth, Labour Market Institution and Macro Policies on Unemployment" Working Paper, SCEPA.

Solow, R.M., (1956). A Contribution to the Theory of Economic Growth, Quarterly Journal of Economics, XXXIV, $1-26$.

Tatoglu, F.Y., (2011). "The long and short term effects between unemployment and economic growth in Europe" Dogus University: Dergisi, 12:99-113.

Thirlwal, A.P. (2006). Growth and development: With special reference to developing economies. $8^{\text {th }}$ edition, New York, Palgrave Macmillan

Todaro, M.P., (1985). Economic Development in the Third World, London.

Tombolo, G.A., \& Hasegawa, M.M., (2014). Okun's Law: Evidence for the Brazilian Economy, on line at http://mpra.ub.uni-muenchen.de/54766/

United Nations (2011). World Population Prospect. The 2010 Revision, New York, UN Population Division.

Viren, M. (2001). The Okun's curve is non-linear. Economics Letters, 70, 253-257

Weber, C.E., (1995). Cyclical Output, Cyclical Unemployment and Okun's Coefficient. A New Approach. Journal of Applied Econometrics, 433-445.

World Bank (2013). World Bank’s Development Indicators, Washington D.C: World Bank.

World Bank (2014) World Development Indicators, Washington D.C: World Bank.

World Bank (2018) World Development Indicators, Washington D.C: World Bank

Zanin, L., \& Marra, G., (2011). Rolling Regression Versus Time-Varying Coefficient Modeling: An Empirical Investigation of the Okun's Law in some Euro Area Countries. Bulletin of Economic Research, 64(1).

\section{Copyrights}

Copyright for this article is retained by the author(s), with first publication rights granted to the journal.

This is an open-access article distributed under the terms and conditions of the Creative Commons Attribution license (http://creativecommons.org/licenses/by/4.0/) 